\title{
RECONHECIMENTO JUDICIAL DAS RELIGIÕES DE ORIGEM AFRICANA E O NOVO PARADIGMA INTERPRETATIVO DA LIBERDADE DE CULTO E DE CRENÇA NO DIREITO BRASILEIRO
}

\begin{abstract}
Judicial recognition of african-rooted religions and the new interpretive paradigm of freedom of worship and belief in brazilian law
\end{abstract}

\section{Ilzver de Matos Oliveira}

Doutor em Direito PUCRio. Professor Pleno do Mestrado em Direito da Universidade Tiradentes. Vice-líder e pesquisador do Grupo de Pesquisa Políticas Públicas de Direitos Humanos - UNIT-CNPq. E-mail: ilzver@gmail.com

RECEBIDO EM: 07.04.2015

APROVADO EM: 04.02.2016

DOI: $10.5585 /$ rdb.v10i5.256

\section{Resumo}

O considerável aumento do número de casos judicializados, nas últimas décadas, envolvendo o direito de liberdade de culto e de crença de religiões e religiosos de origem africana, nos faz acreditar que estamos diante da emergência de um novo fenômeno a ser estudado: a judicialização da religiosidade afro-brasileira. Ele surge marcado pelas manifestações dos tribunais sobre a amplitude e a caracterização do direito ao livre culto e crença nas religiões de matriz africana e do direito à preservação da cultura afro-brasileira, especialmente quando estes estão em colisão com direitos tais como a liberdade de expressão e de opinião, a proteção à criança e ao adolescente, à fauna e à flora, à vida e à integridade física, à saúde e ao sossego. Mas, ao mesmo tempo em que se amplia a busca pelo judiciário para se posicionar sobre tais questões, percebemos que os juízes demonstram alguma dificuldade ou incômodo em lidar com tais situações, seja pelo desconhecimento da temática ou em razão de preconceitos culturais e históricos. Diante desse contexto, a proposta desse artigo é a de analisar as relações entre as religiões e o direito buscando investigar se estas relações interferem na construção ou desconstrução da tolerância e intolerância religiosa e na possibilidade ou impedimento de novos desenhos tanto da atuação do sistema jurídico e judicial nacional na garantia do direito à liberdade religiosa como das relações de tolerância/intolerância religiosa entre as diversas denominações.

Palavras-chave: Religiões de origem africana. Poder Judiciário. Transição parADIGMÁtICA. 


\section{Abstract}

The considerable increase in the number of cases judicialized in recent decades, including the right to freedom of worship and belief of African-rooted religions, make us believe that we are witnessing the emergence of a new phenomenon to be studied: the legalization of african-Brazilian religiosity. It arises marked by manifestations of the courts on the amplitude and the characterization of the freedom to worship and belief in the religions of African origin and the right to preserve african-Brazilian culture, especially when they are in collision with rights such as freedom of expression and opinion, the protection of children and adolescents, fauna and flora, to life and physical integrity, health and peace. But at the same time expanding your search for the judiciary to stand on those issues, we realize that judges demonstrate some difficulty or discomfort in dealing with such situations, either through ignorance or because the theme of cultural and historical prejudices. In this context, the purpose of this paper is to analyze the relationships between religions and the right order to investigate whether these relationships interfere with the construction or deconstruction of tolerance and religious intolerance and the ability or inability of new designs of both the performance of the legal system and national court to guarantee the right to religious freedom as relations of tolerance / intolerance between different religious denominations.

Keywords: African-Rooted RELIGIONS. Judiciary. PARAdigmatic transition.

\section{INTRODUÇÃo}

Regulamentando as expressões de religiosidades em contextos específicos, ou mesmo produzindo releituras de manifestações religiosas no decurso do tempo histórico, o direito, desde a colonização está na zona de contato ${ }^{1}$ entre as religiões e

1 Para Boaventura de Sousa Santos (2003, p.43), as zonas de contato são campos sociais em que diferentes mundos da vida normativos se encontram e defrontam. Para o autor é nesses espaços que diferentes culturas jurídicas se defrontam de modos altamente assimétricos, quer dizer, em embates que mobilizam trocas de poder muito desiguais. As zonas de contato são, portanto, zonas em que ideias, saberes, formas de poder, universos simbólicos e agências normativos e rivais se encontram em condições desiguais e mutuamente se repelem, rejeitam, assimilam, imitam e subvertem, de modo a dar origem a constelações político-jurídicas de natureza híbrida em que é possível detectar o rasto da desigualdade das trocas. Os híbridos jurídicos são fenómenos político-jurídicos onde se misturam entidades heterogéneas que funcionam por desintegração das formas e por recolha dos fragmentos, de modo a dar origem a novas constelações de significado político e jurídico. Em resultado das interações que ocorrem na zona de contato, tanto a natureza dos diferentes poderes envolvidos como as diferenças de poder existentes entre eles são afetadas. A compreensão 
as (1n)tolerāncias religiosas, e muitas vezes as ut1lizam como fontes para a criação de suas normas e decisões judiciais. Por outro lado, sabemos que também as religiões utilizam o direito, sobretudo, quando as próprias religiões procuraram se apropriar do direito enquanto aparato de intenso alcance social, difusor de representações e imaginários coletivos.

Nesse cenário o direito tem assumido alguns importantes papéis. Tem sido em alguns momentos um promotor ou questionador das doutrinas e práticas religiosas; tem causando polêmicas por servir de base para o crescimento no mercado religioso $^{2}$ e/ou político de algumas denominações religiosas; tem polemizado também por entrar em conflito com os dogmas religiosos. Assim sendo, diante da abrangente possibilidade de abordagens e (re)leituras acerca desta temática, este trabalho busca dialogar e problematizar as relações entre religiões e (in)tolerâncias religiosas no direito através da análise da sua atuação no âmbito do direito à liberdade religiosa dos cultos de matriz africana no Brasil.

Partimos da percepção de que o Brasil sempre foi considerado um país de fácil convivência entre os diferentes, inclusive no campo das religiões. Entretanto, nos últimos anos, à medida que a sociedade se torna cada vez mais plural em termos religiosos, paradoxalmente temos assistido a manifestações públicas de intolerância religiosa. Tais manifestações se dão em um contexto político novo de investimento de setores religiosos conservadores na sociedade e no Estado, seja disputando lugares de poder no Executivo, seja conquistando espaços cada vez maiores no Parlamento, ocupando funções no Judiciário, ou ainda, ampliando as possibilidades de incidência social pelo uso do aparato estatal em prol de seus objetivos.

A ampliação do poder político desses grupos expressa-se, entre outros, nas tentativas de reverter avanços em relação a direitos nos campos da sexualidade e da reprodução, afetando diretamente a população homossexual e de mulheres, da educação e da igualdade, atingindo grupos raciais e religiosos historicamente vulnerabilizados, como são as religiões de origem africana e seus adeptos, que serão o objeto deste artigo. Desse modo, emerge a necessidade de, para a compreensão desse quadro problemático, empreendermos a discussão de questões que dizem respeito às articulações entre liberdade religiosa, democracia e a efetivação dos direitos de cidadania em um Estado constitucionalmente laico.

Sobre este aspecto, vemos que as relações entre direito e religiões podem ser compreendidas a partir de dois modelos. Primeiro o da laicidade, entendida de forma inicial como a doutrina ou sistema político marcado pela ausência de uma

deste conceito é fundamental para este trabalho, uma vez que os afrorreligiosos no nosso país são um dos principais exemplos atuais de grupos sociais que se envolvem e têm se envolvido em conflitos assimétricos com culturas nacionais dominantes.

2 Prandi (2004) denomina de "mercado religioso" a oferta de serviços que a religião é capaz de propiciar aos consumidores religiosos e as estratégias de acessar os consumidores e criar novas necessidades religiosas. 
religião oficial e da sua interferência no estado, na cultura, na educação, entre outros espaços de interação social, bem como pela inexistência de subvenção ou embaraço no funcionamento de templos de qualquer religião. Segundo, o da liberdade religiosa, representada pela garantia real de que pessoas e grupos religiosos possam ter e expressar livremente a sua crença e de que seus espaços de culto e suas liturgias sejam protegidos contra qualquer interferência injusta.

Nesse contexto, o direito se tornou uma importante arena de disputa entre os diferentes grupos concorrentes no mercado religioso e um receptáculo das tensões que envolvem as diferentes visões de mundo dessas religiões sobre questões sociais, econômicas, políticas, entre outras, e sobre as outras crenças e suas liturgias. Em torno dessas disputas foram mobilizadas as agendas de importantes Movimentos Sociais e Políticos e de grupos religiosos. Dentro dessa agenda, encontramos demandas que foram levadas, por exemplo, diante dos tribunais brasileiros, legítimos interpretadores das normas e responsáveis pelo apaziguamento dos conflitos sociais. Desde o célebre "caso Mãe Gilda", ocorrido em 1999, que chegou ao Su-

3 Assim ficou popularmente conhecida a ação de intolerância religiosa praticada pela Igreja Universal do Reino de Deus - lurd, contra a Yalorixá Gildásia dos Santos e Santos - a Mãe Gilda. A lurd publicou uma fotografia da Yalorixá no jornal Folha Universal, em outubro de 1999, associada a uma reportagem sobre charlatanismo, sob o título: "Macumbeiros charlatões lesam o bolso e a vida dos clientes". A matéria afirmava estar crescendo no País um "mercado de enganação". Nesta reportagem, a foto da Mãe Gilda, aparece com uma tarja preta nos olhos. A Folha Universal tinha na época uma tiragem de 1.372 .000 unidades, ampla e gratuitamente distribuídas. A comunidade local tomou conhecimento da reportagem e, por uma falta de compreensão do que estava acontecendo, até integrantes de sua própria comunidade interpretaram que a Mãe Gilda havia se convertido e estava pregando contra sua religião, pois sua foto estava naquele veículo. Em conseqüência disso, a Yalorixá caiu no descrédito perante os seus fiéis e muitos deles se afastaram do seu Terreiro. Além disso, dada à grande exposição e fragilidade, adeptos de outras religiões sentiram-se no direito de atacar diretamente a Casa da Mãe Gilda, agredindo-a e ao seu marido, verbal e fisicamente, dentro das dependências do Terreiro, até quebrando objetos sagrados lá dispostos. Diante destes fatos, com a saúde fragilizada, Mãe Gilda não suportou, teve um infarte e veio a falecer no dia 21 de janeiro de 2000. Logo após à morte da Mãe Gilda, seus filhos moveram uma ação contra a lurd, por danos morais e uso indevido da imagem. Cinco anos depois do início do processo, em 2004, a lurd foi condenada em primeira instância, ficando estabelecido o ganho de causa da ação de Mãe Gilda. A sentença, favorável à ação indenizatória, condenou a lurd e a sua gráfica a publicar a sentença na capa e encarte do Jornal Universal por duas tiragens consecutivas; condenou a lurd e a sua gráfica a indenizar a família em $\mathrm{R} \$$ 1.372.000 (fazendo a equivalência de $\mathrm{R} \$ 1,00$ para cada exemplar da Folha Universal distribuído); determinou que o Ministério Público abrisse processo criminal contra a IURD. Após apelação na segunda instância, em 6 de julho de 2004, o Tribunal de Justiça da Bahia julgou e condenou, por unanimidade, a Igreja Universal do Reino de Deus por danos morais e uso indevido da imagem da Yalorixá Mãe Gilda, apenas reduzindo o valor da indenização para R\$960.000,00. Insatisfeita com o resultado, a lurd recorreu da decisão, apelando para Superior Tribunal de Justiça - STJ em Brasília, bem como ao Supremo Tribunal Federal - 
perior Tribunal de Justiça e resultou na primeira condenação nacional por dano moral decorrente de intolerância religiosa institucional e no estabelecimento, através da Lei federal n ${ }^{\circ} 11.635$ de 2007, do Dia Nacional de Combate à Intolerância Religiosa, comemorado no dia 21 de janeiro, até os casos de cobrança de impostos dos templos religiosos afro-brasileiros ou contra yalorixás e babalorixás por má prestação de serviço; as ações que equiparam templos afro-religiosos a estabelecimentos comerciais, que criminalizam afro-religiosos por cárcere privado ou de lesão corporal durante cerimônias de iniciação, que fecham templos afro-brasileiros sob a alegação de perturbação do sossego, poluição sonora, poluição ambiental e maus-tratos a animais; entre outros, o que percebemos atualmente é que os tribunais têm se constituído num dos principais espaços de discussão sobre os direitos relativos a essa parcela da população, historicamente discriminada por sua crença religiosa.

Recentemente, gerou grande polêmica nacional a decisão judicial proveniente do processo $\mathrm{n}^{\mathrm{o}}$ 0004747-33.2014.4.02.5101 e escrita pelo magistrado Eugenio Rosa de Araújo, juiz federal titular da $17^{\circ}$ Vara Federal no Rio de Janeiro, resultado de uma Ação Civil Pública ajuizada pelo Ministério Público Federal em desfavor do Google Brasil Internet LTDA. com o objetivo de ver retirado do sistema Google vídeos em que membros da Igreja Universal do Reino de Deus aviltavam as religiões afro-brasileiras, seus símbolos, ritos e seus sacerdotes. O fato é que a decisão do juiz negou o pedido de retirada dos vídeos da internet sob o fundamento que no caso concreto somente existiu uma concorrência entre direitos fundamentais e não uma violação aos direitos de liberdade de consciência, liberdade de crença, proteção às liturgias religiosas, liberdade opinião, de reunião e de religião. E mais, a decisão definiu que o candomblé e a umbanda não continham os traços necessários de uma religião a saber: um texto base (tal qual o Corão ou a Bíblia); estrutura hierárquica; e, ainda, um deus a ser venerado. Em seguida, a decisão indicou que os vídeos constantes no Google não seriam uma ofensa às liberdades públicas e tão pouco colocavam em risco a prática cultural das manifestações afro-brasileiras.

Casos judicializados como os descritos acima, além de inúmeros outros existentes na literatura sobre direito e relações raciais brasileiras ${ }^{4}$, nos fazem acreditar que estamos diante da emergência de um novo fenômeno a ser estudado: a judicialização da religiosidade afro-brasileira. Ela surge marcada pelas manifestações dos tribunais sobre a amplitude e a caracterização do direito ao livre culto e crença

STF. Este último não aceitou o pedido, julgando-o improcedente. No dia 16 de setembro de 2008, o Superior Tribunal de Justiça confirmou, também por unanimidade, a condenação da Igreja Universal do Reino de Deus, em que esta ficava obrigada a publicar retratação no jornal Folha Universal e a pagar indenização, reduzida de $\mathrm{R} \$ 1,4$ milhão, conforme decisão da 1 a instância, para $\mathrm{R} \$ 145.250,00$.

4 Nessa temática, importantes os estudos de Hédio Silva Júnior e Vagner Gonçalves da Silva na obra Intolerância Religiosa: impactos do neopentecostalismo no campo religioso afro-brasileiro (2007). 
nas religiões de matriz africana e do direito à preservação da cultura afro-brasileira, especialmente quando estes estão em colisão com direitos tais como a liberdade de expressão e de opinião, a proteção à criança e ao adolescente, à fauna e à flora, à vida e à integridade física, à saúde e ao sossego.

Por todo esse contexto nossa proposta aqui é analisar as relações entre as religiões e o direito buscando investigar se estas relações interferem na construção ou desconstrução da tolerância e intolerância religiosa e na possibilidade ou impedimento de novos desenhos tanto da atuação do sistema jurídico e judicial nacional na garantia do direito à liberdade religiosa como das relações de tolerância/intolerância religiosa.

Quanto ao referencial teórico foram utilizadas as contribuições de alguns dos principais e primeiros estudiosos sobre a religião e a cultura afro-brasileira em nosso país: Nina Rodrigues, Arthur Ramos, Édison Santos, Roger Bastide, entre outros. Agregamos a esse primeiro marco teórico sobre cultos africanos no Brasil, as contribuições mais recentes de autores como Reginaldo Prandi, Sérgio Ferretti, Beatriz Góis Dantas, e outros. Outras importantes fontes utilizadas nesta pesquisa vieram de autores que se debruçaram sobre o estudo da liberdade religiosa, do direito e da justiça. Destacamos neste grupo aqueles que refletiram especificamente sobre o tema em relação aos afrorreligiosos: Hédio Silva Júnior, Mundicarmo Ferretti, Yvonne Maggie e outros.

\section{A BAIXA CONSIDERAÇÃO À RELIGIOSIDADE DE ORIGEM AFRICA- NA E A SUA LUTA POR RECONHECIMENTO ENQUANTO RELIGIÕES}

O lugar de subalternidade destinado às religiões afro-brasileiras, por serem expressão religiosa dos grupos dominados (escravos, trabalhadores forçados, pessoas livres de cor, indígenas, etc.), além de se constituir num estratégia de discriminação e perseguição, permitiu o deslocamento dos cultos de origem africana do campo religioso e promoveu a sua aproximação cada vez maior com as manifestações do folclore brasileiro, com expressões da cultura afro-brasileira e nacional e o seu consequente afastamento da identificação com uma religião ou com o sagrado no imaginário popular.

A construção dessa ideia de maior familiaridade com o campo cultural e lúdico fez com que os cultos de origem africana fossem ainda mais atrelados ao profano e ao popular, enquanto se ampliava a rejeição da sua identidade como religião.

Esse panorama fez surgir um dos maiores problemas jurídico-constitucionais que os afrorreligiosos enfrentaram no passado e ainda enfrentam na atualidade: afinal, como garantir a liberdade religiosa de uma religião que não é considerada como religião, e quando muito é reconhecida como manifestação das culturas populares ${ }^{5}$ ?

5 Na Seção denominada "Da Cultura", no Título VIII "Da Ordem Social”, o Art. 215 da Cons- 
Dentre os estudiosos das religiões de origem africana, Carneiro (1959), refletindo sobre a questão do lugar desses cultos na Bahia, apontava que as crenças religiosas afro-brasileiras "já se estão encaminhando parcialmente para o seu destino lógico - o folclore" (p. 18).

Festas outrora celebradas no recesso dos cultos, como as de Yêmanjá e dos gêmeos ${ }^{6}$, conquistaram a Bahia, como as cerimônias propiciatórias do Ano Novo tomaram para si as praias cariocas. Em São Luis, o tambor, de mina e de nagô, deu um produto profano - o tambor de crioulo. Ao antigo cortejo dos reis do Congo aderiram os cultos da Bahia e do Recife, criando os folguedos que agora conhecemos como afóxés e maracatus. Os antigos cucumbis, predecessores dos atuais cabocolinhos e caiapós, a capoeira, o Caxambu e o jongo tomaram corpo sob o estímulo das crenças trazidas da África. (CARNEIRO, 1959, p. 18-19).

Para Carneiro (1959), ao passarem da dimensão da religião para a da di-

tituição Brasileira de 1988 diz que "O Estado garantirá a todos o pleno exercício dos direitos culturais e acesso às fontes da cultura nacional, e apoiará e incentivará a valorização e a difusão das manifestações culturais." E complementado o enunciado do caput do artigo, o §1으 estabelece: "O Estado protegerá as manifestações das culturas populares, indígenas e afro-brasileiras, e das de outros grupos participantes do processo civilizatório nacional." Mas, não são apenas estes traços que destacam a preocupação da Constituição brasileira com a chamada por ela "cultura popular". O Art. 216 prescreve que "Constituem patrimônio cultural brasileiro os bens de natureza material e imaterial, tomados individualmente ou em conjunto, portadores de referência à identidade, à ação, à memória dos diferentes grupos formadores da sociedade brasileira, nos quais se incluem: I - as formas de expressão; II - os modos de criar, fazer e viver; III - as criações científicas, artísticas e tecnológicas; IV as obras, objetos, documentos, edificações e demais espaços destinados às manifestações artístico-culturais; V - os conjuntos urbanos e sítios de valor histórico, paisagístico, artístico, arqueológico, paleontológico, ecológico e científico. E o $\$ 1$ 으 destaca que "O Poder Público, com a colaboração da comunidade, promoverá e protegerá o patrimônio cultural brasileiro, por meio de inventários, registros, vigilância, tombamento e desapropriação, e de outras formas de acautelamento e preservação." É dessa forma que a Constituição de 1988 abre espaço para a proteção da cultura popular afro-brasileira: estabelecendo-a dentro do rol daquele tipo de norma chamada de programática ou seja, que possui eficácia e aplicabilidade dependente de regulamentação ulterior, e submetida ao princípio da reserva do economicamente possível.

6 É no final dos anos 60 e começo dos 70 que se inicia junto às classes médias a recuperação das nossas raízes culturais, reflexo de um movimento cultural muito mais amplo, que, nos Estados Unidos e na Europa, e daí para o Brasil, questionava as verdades da civilização ocidental, o conhecimento universitário tradicional, a superioridade dos padrões burgueses vigentes, os valores estéticos europeus, voltando-se para as culturas tradicionais, sobretudo as do Oriente, e buscando novos sentidos nas velhas subjetividades, em esquecidos valores e escondidas formas de expressões. (PRANDI, 2000, p.63). 
versão cultural e da ludicidade, novos setores da população tiveram contato com as crenças e práticas básicas dos cultos de origem africana, de modo que para ele há pontos positivos e negativos nessa transmutação histórica dos cultos de origem africana de religião para folclore: "se contribuem para a desagregação deles como unidades religiosas relativamente compactas, também reforçam, tornando-os mais compreensíveis e aceitáveis" (p. 19) e essa maior interação social com tais crenças auxiliaria na sua manutenção e multiplicação. (CARNEIRO, 1959, p. 18-19).

Apresentando-se contrário à visão de Carneiro, Freyre (1947, p. 172) diz que a redução da religião do negro a formas lúdicas e de dança se fundamenta numa visão ideologizada das elites brancas que apresentavam o africano como tendo a dança "impregnada no sangue" e, portanto, tendendo a "reduzir tudo à dança - trabalho ou jogo".

Para Prandi (2000, p. 63-64) ficou no passado a ideia de candomblé como uma referência cultural negra:

Se aspectos de origem africana compunham a cultura brasileira nas mais diversas áreas, com o movimento dos anos 60 e 70 ocorreu todo um redimensionamento da herança negra, com o qual aquilo que antes era tratado como exótico, diferente, primitivo, passou a ser incorporado como habitual, próximo, contemporâneo. A própria música popular incorpora ao velho e sucessivamente branqueado samba novas batidas, mais próximas da percussão dos terreiros de candomblé. As escolas de samba do carnaval não se cansam de fazer desfilar os orixás na avenida. A televisão, na notícia e na ficção, não consegue deixar de lado referências constantes aos deuses dos terreiros, ao jogo de búzios, aos falsos e autênticos pais e mães-de-santo. A cultura de uma minoria agora já é consumo de todos.

Outros autores ao discutirem as aproximações entre cultos afro-brasileiros e folclore, destacam os termos subcultura e de religião popular para a compreensão do alcance desse debate e para diferenciar aquilo que é religião do que podemos chamar de folclore. É o que faz, por exemplo, Ferretti (1999), ao trabalhar com as ideias de religião e cultura popular em Antônio Gramsci para compreender as religiões afro-brasileiras no Maranhão.

Ferretti parte da consideração do folclore como subcultura produzida pelas classes subalternas nas sociedades de classes. Assim, os cultos de origem africana seriam religiões populares, pois produzidos por negros da classe dominada e também por serem uma herança cultural de escravos, atualizada por seus descendentes. Mas, não só, para o autor tais religiões podem ser identificadas como populares, pois se constituem de fato em manifestação da cultura popular em "contraposição à cultura oficial, hegemônica, numa sociedade que se pretende branca e católica" (FERRETI, 1999, p. 6). 
No Brasil até os dias atuais, apesar da queda do número de auto-identificados católicos, a sociedade se considera católica. Seja social ou estatisticamente os números ainda apontam o predomínio da religiosidade católica entre os brasileiros. Sobre este aspecto, Ferreti diz que o "catolicismo é de fato uma religião semi-oficial ou quase oficial" e apresenta algumas situações explicativas para esta afirmação:

- Para a sociedade civil, as autoridades religiosas são quase que exclusivamente as autoridades católicas. Ainda desfrutam de grande prestígio e poder, exercendo até hoje na maior parte do país, função de coerção e de inculcação; (FERRETI, 1999, p. 6).

- As escolas católicas (função ideológica) são muito prestigiadas na sociedade brasileira. O casamento religioso católico, a missa de sétimo dia, são cerimônias que fazem parte da esfera oficial. (FERRETI, 1999, p. 6-7).

Segundo Soares (2009), a subalternidade tende a ser compreendida como uma forma de dominação, ou seja, grupos subalternos assujeitam-se e sofrem a influência dos valores da cultura dominante. Para ele,

[...] as religiões subalternas: são aquelas formas de religiosidades forjadas no seio de relações de poder, conflitos que se resolvem no jogo social, constituídas numa dinâmica específica e submetendo-se à justaposição ou sobreposição de discursos religiosos, e dada sua gênese metamórfica sob atuação íntima do homem culturalmente dotado de uma ideia que resignifica um signo ou seu primeiro significado. (SOARES, 2009, p.135).

Assim, verificamos como e porque o catolicismo continua fazendo parte da concepção de mundo da classe dirigente seja no âmbito social, político ou mesmo no judicial. E como as religiões afro-brasileiras se contrapõem a esta cultura oficial e apresentam-se perante ela como religiões representativas dos extratos inferiores da sociedade ${ }^{7}$, contestadora da autoproclamada universalidade da religião católica, o cristianismo, que etnocentricamente se estabelece como religião, em reação, as considera como não religiões. (FERRETTI, 1999, p.7).

Para Gramsci existe cultura popular na medida em que existe cultura dominante. A cultura popular assume em face da cultura dominante uma posição diversa, contestadora por posição, da autoproclamada universalidade da

7 Essa representação é contestada pelos dados estatísticos dos Censos brasileiros, quando verificamos que os cultos de origem africana encontraram maior adesão das pessoas enquadradas nas classes econômicas $A B$. O catolicismo possui mais adeptos nas camadas mais pobres $(72,76 \%$ na classe $E)$, apesar de possuir representatividade dentre as classes elitistas (69,07\% nas classes $A B)$. Isso reforça a nossa defesa de que a relação entre religiões de matriz africana e as classes inferiores da sociedade extrapola as análises meramente estatísticas e relaciona-se à história da origem de tais crenças e aos grupos étnicos a ela originariamente relacionados. 
cultura dominante. As religiões afro-brasileiras também podem ser vistas como assumindo o papel contestador da hegemonia do catolicismo. No Brasil a cultura intelectual também se torna prerrogativa da classe dominante, pois nas sociedades de classe, opera como refere Gramsci, uma série de instituições e mecanismos tendentes a levar as classes subalternas a conformar sua inferioridade. A religião popular também é desvalorizada como religião do povo, como coisa de negro, como religião inferior, como magia e não como religião. $\mathrm{O}$ atraso cultural das classes subalternas é considerado como decorrência de seu atraso econômico. (FERRETI, 1999, p.7).

Diante deste quadro, os cultos afro-brasileiros iniciam uma luta por reconhecimento que se utiliza de várias estratégias, dentre as quais Ferreti destaca: a) as religiões afro-brasileiras para se verem reconhecidas utilizam elementos do simbolismo católico como missas, procissões, imagens de santos, festas religiosas, etc; b) seus participantes em geral se dizem católicos e as práticas especificamente de origem africana são consideradas como elementos de acréscimo ${ }^{8}$. (FERRETTI, 1999, p. 6-7).

Assim, contrariamente a Carneiro (1959), Ferretti (1999) defende que é necessário perceber que religião e folclore são fenômenos distintos. E quase como uma resposta ao dito por Edison Carneiro em 1959 sobre que "em São Luis, o tambor, de mina e de nagô, deu um produto profano - o tambor de crioulo." (CARNEIRO, 1959, p.19), Ferreti explica que o próprio povo faz lá no Maranhão muito claramente esta distinção entre religião e folclore, distinguindo o tambor de crioula ${ }^{9}$ - manifestação folclórica -, do tambor de mina - manifestação religiosa.

Acontece, entretanto que as religiões populares englobam diversas manifestações folclóricas. Muitas vezes elas se desenvolvem no mesmo local, sendo realizadas pelas mesmas pessoas, embora em circunstâncias e ocasiões distintas. Como as religiões afro-brasileiras incluem em seus ritos festas, músicas, danças, instrumentos populares e cânticos, elas estão muito próximas das manifestações da cultura popular. No tambor de mina do

8 Trata-se do fenômeno do sincretismo religioso afro-católico, que é explicado por Roger Bastide como fazendo parte do processo de interpenetração de civilizações, pelo princípio de cisão, segundo qual ideias e princípios de origens distintas coexistem sem conflitos para seus adeptos.

9 O tambor de crioula é uma dança própria do Maranhão, na qual os tambores são acompanhados por versos de improviso. É o som dos tambores que se ouve em festas públicas. Aos homens cabe cantar e tocar três tambores de madeira de tamanhos diferentes, enquanto as mulheres dançam. Conta-se no Maranhão que São Benedito gosta de tambor de crioula e por isso muitas promessas ao santo são pagas com uma festa de tambor de crioula. (ALBUQUERQUE E FRAGA FILHO, 2006, 240). 
Maranhão encontramos, por exemplo, diversos elementos do catolicismo popular como procissões, ladainhas, devoções e santos juntamente com outros elementos do folclore, como festas de tambor de crioula, bumbameu-boi, pastores, festas do Divino, dança do carimbó, etc. Estes elementos do folclore maranhense estão muito próximos do tambor de mina pois seus participantes em grande parte são os mesmos, pertencendo ao mesmo grupo étnico e à mesma classe social, em sua maioria participante do segmento negro da classe dominada. Grande parte das casas de tambor de mina são também núcleos em torno dos quais se desenvolvem outras manifestações da cultura popular. (FERRETI, 1999, p.8).

Para Ferretti (1999) podemos entender religião popular, e cultura popular, como formas de contestação à cultura hegemônica, mas é imperativo reconhecer que as religiões afro-brasileiras são religiões como as outras e desse modo se distinguem de manifestações folclóricas, inclusive quando esse reconhecimento é solicitado aos intérpretes das leis. Estes precisam compreender que a multiplicação de denominações religiosas é consequência da limitação às liberdades políticas, pois na medida em que o aparelho do Estado proíbe a livre formação de organismos políticos, a única possibilidade de expressão popular que subsiste é a da religião e a formação de novas denominações religiosas. Essa é uma concepção embasada nas ideias desenvolvidas por Roger Bastide, para o qual "a resistência se torna religiosa quando não pode tomar a forma política. A religião é a única via aberta, quando todas as outras saídas estão fechadas." (BASTIDE, 1985, p. 220).

Para Ferretti (1999) essa pode ser uma das formas de compreensão e explicação para o surgimento, a partir de meados do século XIX, em várias partes do país, de numerosos grupos religiosos afro-brasileiros e de seu grande vigor principalmente em épocas de perseguições às liberdades, como no Estado Novo, na ditadura militar e em diversos outros períodos de repressão. É também uma das formas de explicação da atual proliferação de expressões religiosas as mais distintas que se expandem sobretudo nos ambientes populares. Frente ao controle do aparelho político, o aparelho religioso torna-se o modo essencial de expressão dos grupos sociais subalternos. Nos primeiros séculos as religiões de origem africana, adotaram também a estratégia de uma revolução passiva, de resistência não violenta, como movimento do povo oprimido e das classes subalternas, mas, é necessário ressaltar, entretanto, que hoje no Brasil, estas religiões não são mais religiões exclusivamente de negros e das classes subalternas, assim indicam as análises estatísticas sobre as religiões no nosso país. Elas abrangem populações de todas as cores e classes, apesar de não perderem a pertença às categorias e grupos que lhes deram origem. E, além disso, atualmente as perseguições religiosas no Brasil tomaram outra feição, saindo mais do campo estatal e indo para o âmbito das relações privadas, por isso é preciso reconhecer que tanto pelas manifestações dos órgãos do aparelho estatal quando dos 
cidadãos e suas entidades organizativas e religiosas, persistem, entretanto, os preconceitos, e a religião dos negros continua sendo marginalizada e pouco conhecida. (FERRETTI, 1999, p.8).

A questão é perceber que apesar de terem se organizado mesmo diante de todas as dificuldades, africanos e afro-brasileiros não tinham liberdade plena para cultuar seus santos e deuses, apesar de muitas vezes terem permissão para fazê-lo. E se concordamos que permissão não é liberdade plena, podemos afirmar que tais cultos não eram livres em nosso país e corroboraremos com uma das ideias defendidas nesta pesquisa: que a intolerância que atinge as religiões de matriz africana no Brasil "conforma uma das facetas do racismo brasileiro" (SILVA Jr., 2007, p. 303).

O processo do tráfico de escravos foi um fator decisivo para os processos de assujeitamento e de construção das identidades e da subjetividade subalternas do negro brasileiro ${ }^{10}$. Roger Bastide acredita que "a escravidão destruiu toda a organização social dos negros africanos [...] mas deixou intacto o mundo dos valores, das ideias e das crenças religiosas"; e também que "a escravidão causou uma fissura entre as superestruturas e as infra-estruturas. As estruturas sociais africanas foram quebradas, os valores foram conservados [...] As superestruturas tiveram que secretar a sociedade" (BASTIDE, 2001, p. 211-212).

Por isso discordamos de algumas posições de Prandi (2000), sobretudo de que vivemos no Brasil o culminar do processo de "diluição e apagamento étnico" (p.59), de um período onde o norte orientador não é mais "a diferença, o pluralismo cultural e a valorização das origens étnicas" (p. 59) e que "já estávamos na sociedade de massa e o candomblé seria o grande reservatório da cultura brasileira mais próxima da África." (p.63):

A cultura africana que assim vai se diluindo na formação da cultura nacional corresponde a um vastíssimo elenco de itens que abrangem a língua, a culinária, a música e artes diversas, além de valores sociais, representações míticas e concepções religiosas. Mas, fora do campo religioso, nenhuma das instituições culturais africanas logrou sobreviver. Ao contrário, cada contribuição é o resultado de um longo e lento processo de diluição e apagamento étnico a tal ponto que, diante de um determinado traço cultural, embora podendo reconhecer uma origem africana genérica, ainda assim

10 Segundo Fausto (1996, p.41), a escravidão foi uma instituição nacional que penetrou toda a sociedade, condicionando seu modo de agir e de pensar. Essa penetração gerou o desejo de ser dono de escravos, o esforço por obtê-los, tanto em indivíduos da classe dominante como das classes trabalhadoras. "Houve senhores de engenho e proprietários de minas com centenas de escravos, pequenos lavradores com dois ou três, lares domésticos, nas cidades, com apenas um escravo. O preconceito contra o negro ultrapassou o fim da escravidão e chegou modificado a nossos dias." Para o autor, até pelo menos a introdução em massa de trabalhadores europeus no centro-sul do Brasil, o trabalho manual foi socialmente desprezado como "coisa de negro". 
é difícil, quando não impossível, identificar o povo ou nação de que provém. Tudo é simplesmente África, perdidas as diferenças e especificidades. Mais que isso, os próprios afro-descendentes, por não conhecerem sua própria origem, nem sabendo se seus antepassados eram bantos ou sudaneses, também não podem identificar as origens dos aspectos culturais, como se a cultura brasileira como um todo, ao se apropriar deles, tivesse apagado as fontes.

Não concordamos porque defendemos que a construção e a afirmação de uma identidade étnica pode também ser pensada como uma forma de luta política pelo poder, de modo a afirmar a diferença, indo além de um "resgate" da tradição negra. Esta construção reflete possivelmente a criação de um "nós coletivo", na formação de um grupo que está, sobretudo, interessado em reivindicar uma maior visibilidade social face ao apagamento a que foi submetido no passado. Essa construção de uma identidade negra a partir de religiões afro-brasileiras pode ser encarada como um fato significativo para a construção desta identidade.

E discordamos também porque tanto pela origem da religiosidade, o solo africano, quanto pela marca racial nela impressa, a negra, fato é que percebemos que os atos de repressão aos cultos afro-brasileiros vivenciados na história do nosso país, e ainda hoje visualizados em vários cantos do Brasil, no espaço público ou no privado, estão relacionados diretamente com o nosso período escravocrata e com as teorias raciais criadas em torno da figura do negro africano e afro-brasileiro: não civilizado, inferior, atrasado, aculturado, selvagem, místico, mágico, perigoso, lascivo, desordeiro, dentre outras.

E ressaltamos que tais teorias criadas especialmente para justificar a dominação branca sobre os povos negros traficados, para conter as revoltas da massa negra escravizada e para impedir atos de oposição ao regime escravocrata então vigente, do mesmo modo que foram sustentadas pela Ciência, que criou teorias para sustentar a ideia de inferiorização da raça negra e de suas tradições, também contou fortemente com o apoio do Direito.

Assim, o Direito serviu como uma das armas para o modelo brasileiro de relações raciais, que "mesmo em sua versão pós-abolição, teria prescindido do suporte, do aparato, da força da lei na imposição de suas regras de funcionamento". (SILVA Jr., 2007, p. 303). Desse modo, através de leis supostamente neutras, pois na maioria das vezes não se referiam explicitamente ao negro ${ }^{11}$, apesar de repletas de objetivos políticos e ideológicos, especialmente os relacionados ao extermínio da cultura e da religiosidade do africano e do afro-brasileiro, o sistema jurídico garantiu

11 De forma distinta a esta ideia de neutralidade legal, em Sergipe, por exemplo, José Eloy Pessoa, Coronel nomeado em 5.4.1837, empossado em 31.5.1837, deixando o cargo em 23.3.1838 Presidente da Província de Sergipe Del Rey, por Decreto, proibiu que Negros, Escravos, Africanos, Pretos, Mulatos e Leprosos, frequentassem as escolas. 
o controle da população negra pelas classes dominantes.

Salvo melhor juízo seria possível informar que também nestas plagas, por muito tempo, incluído o século passado, a função da lei, especialmente da lei penal, como também do sistema penal, não esteve totalmente dissociada do modelo de relações raciais e, por extensão, do padrão religioso adotado pelos colonizadores e senhores de engenho. (SILVA Jr., 2007, p. 304).

A Constituição do país, promulgada em 1824, definiu o catolicismo como religião oficial do Império, sendo outras religiões permitidas desde que não ostentassem templos. Mas as religiões afro-brasileiras não estavam incluídas nessa tolerância legal porque não eram consideradas religião, e sim superstição, curandeirismo, feitiçaria. Por isso eram vistas como práticas ilegais e muitas vezes criminosas. Reprimir ou tolerar dependia do momento e das circunstâncias. Em todo o país durante o Império, as festas das irmandades negras e os batuques foram severamente reprimidos. A maioria das câmaras municipais aprovou leis proibindo batuques, danças e tocadas de pretos. Em parte essa legislação terminou surtindo os efeitos desejados pelas elites imperiais, pois, até o final do século, a quantidade de pessoas e a pompa das procissões diminuíram sensivelmente. Depois da independência, as autoridades passaram a proibir danças e procissões organizadas pelas irmandades. As autoridades justificavam essas proibições afirmando que as festas causavam bebedeiras e incomodavam a vizinhança. Na verdade, as autoridades temiam e tentaram impedir que as festas dessem lugar a desafios contra a ordem estabelecida. (ALBUQUERQUE e FRAGA FILHO, 2006, p. 111-112)

Ainda falando de Direito, legislação e relações raciais no Brasil, Medeiros (2004, p. 99) diz que o que diferencia as legislações brasileira e americana é que aqui no Brasil "a questão da raça tem sido tratada como uma não-questão, como se a lei não tivesse um papel a desempenhar nesse domínio, uma vez que seriam mínimos os problemas raciais." Enquanto isso, nos Estados Unidos de forma clara é possível perceber o uso da legislação, mesmo após a abolição, "como instrumento de dominação dos negros pelos brancos e, mais tarde, transformados em instrumentos de mudança social."

Silva Jr. (2007) e Dantas (1988) discutem nos seus estudos o tema da existência ou não de leis de caráter racista e discriminatório contra os negros, contra a sua cultura e religiosidade.

Para o jurista paulista a hipótese de inexistência de leis de cunho racial na história do nosso país, que validaria a ideia de que vivemos numa democracia racial, é uma falácia. Para o autor, da colônia à república, não há "um único período histórico no qual a lei, notadamente a lei penal, permanece infensa ao modelo de relações raciais." (SILVA Jr., 2007, p. 304), e se aquela hipótese fosse comprovada, ainda teríamos uma saída interpretativa para contestá-la: que "o modelo de relações raciais 
terá sido tão engenhosa e poderosamente estruturado que a lei teria se tornado perfeitamente dispensável para o seu bom funcionamento". (SILVA Jr., 2007, p. 304).

Para a antropóloga sergipana, entretanto, há dois momentos históricos distintos sobre este processo de acusação legal contra os cultos afro-brasileiros: o primeiro, sob a égide do Código Criminal de 1830, que não incluía a perseguição aos feiticeiros, pois, segundo a autora, embora a religião dos negros fosse vista como feitiçaria, não sentiram os legisladores brasileiros necessidade de controlá-la através da lei enquanto vigorou a escravidão; e o segundo momento, quando os negros já estão livres e, sob a vigência do Código Penal de 1890 passam a ser incriminados não só o curandeiro, mas também o feiticeiro, juntamente com outras categorias como espiritistas e cartomantes.

Assim os autores concordam que o Direito e a legislação serviram como instrumentos de repressão aos cultos afro-brasileiros, mas, discordam que esta opressão legal tenha existido durante toda a história legal do nosso país. Mas o fato é que as religiões de origem africana no Brasil foram submetidas a rígido controle social, político, legal e jurídico ao longo de suas trajetórias históricas. Essas religiões foram severamente reprimidas e impedidas de se expressarem e tiveram de encontrar alternativas e maneiras de viverem e de se manifestarem.

Como em todo o mundo, no Brasil a liberdade religiosa também apresentou diversas faces ao longo dos séculos. Do mesmo modo, sua concepção jurídica também se mostrou variada através das tantas Constituições Federais que o país outorgou ou promulgou. Assim, a importância desse artigo que busca refletir sobre a necessidade de discussão sobre os parâmetros sobre os quais vem sendo pensada a liberdade religiosa no Brasil e as formas de se garantir a todos os cultos e crenças a máxima e mais efetiva proteção jurídico-constitucional e o reconhecimento legal e jurídico.

\section{DE FEITIÇARIA A RELIGIÃO E AS COMPLEXIDADES DA NOMEN- CLATURA}

Ao que nos referimos quando falamos de religiões afro-brasileiras? E cultos de origem africana? O que são religiões de matriz africana? Por que alguns as chamam de religiões de presença africana? É politicamente correto denomina-las de macumba ou feitiçaria? Quais os problemas e preconceitos que envolvem essas nomenclaturas?

Para iniciar nossa discussão e na tentativa de encontrarmos respostas para essas perguntas, retomamos os estudos de Berkenbrock (1998) e Maggie (2001), para dizer aquilo que talvez esteja claro na nomenclatura advinda da junção dos adjetivos gentílicos e étnicos - africano + brasileiro -, ou seja, que do ponto de vista histórico a África é o campo de origem, e o Brasil o campo de desenvolvimento das religiões afro-brasileiras. Assim, para Berkenbrock as religiões africanas formam 
a base sobre a qual se desenvolveram essas religiões no nosso país, a partir da influência tanto de outras religiões (cristianismo, cultos ameríndios, espiritismo, etc), quanto contextuais (escravatura, repressão aos cultos, carência de líderes religiosos, etc). Por sua vez, Yvonne Maggie (2001, p. 13-14) diz que o próprio nome genérico afro-brasileira - expressa uma religião sincretizada: afro, traços africanos, colocados no nível mais baixo de evolução e, brasileira, traços indígenas, católicos e espíritas, respectivamente, colocados nos níveis mais elevados de evolução ${ }^{12}$.

Sendo seus membros negros, suas crenças deveriam ser condizentes com o estágio "primitivo" e por que não "inferior" dessa raça. Mais tarde, com o aprimoramento das abordagens científicas, o primitivismo foi associado às camadas mais baixas da população brasileira que, com forte contingente negro, adotavam essas religiões por não terem ainda alcançado estágios mais altos da evolução cultural, a "civilização". (MAGGIE, 2001, p. 14).

No próximo item faremos um perfil panorâmico e genérico de tais religiões, simplesmente com o objetivo de informar desde o primeiro traço deste texto, o leitor atento e interessado da complexidade e importância dessa discussão.

\subsection{A DIVERSIDADE DE RELIGIÕES DE ORIGEM AFRICANA NO BRASIL}

Feitas estas ponderações introdutórias, e cientes das dificuldades que um pesquisador do Direito teria ao decidir transitar pelos meandros da antropologia de matriz étnica, procuramos o auxílio daquele que é tido como um dos principais sistematizadores e estudiosos dos cultos de origem africana na Bahia, Edison Carneiro, que na sua obra "Candomblés da Bahia", ao tratar da diversidade de designações dadas às religiões de origem africana ${ }^{13}$ nas várias Regiões e Estados do Brasil, nos

12 Com o crescimento das cidades a oposição civilizado-não civilizado é substituída pela oposição rural-urbano, onde o rural foi associado aos traços primitivos, emocionais e não racionais, ou seja, aos traços africanos, e o urbano foi associado aos traços mais civilizados, não emocionais e racionais, ou seja, aos traços espíritas. Esta estratégia servia para abrandar os estereótipos e os preconceitos. "Chamar essas religiões de afro escondia um medo de chama-las de religiões negras. As origens africanas lhe davam um caráter mais 'limpo e aristocrático'. A África está longe, os africanos são estrangeiros e isso lhes confere um outro status. (MAGGIE, 2001, p. 16).

13 Nas suas obras, Rodrigues (1932), Ramos (1940) e Carneiro (1948) destacam três origens para as religiões afro-brasileiras: os bantos (congo e angola), os sudaneses (jejê-nagô) e os malês (mulçumanos). Neste trabalho não estudaremos os aspectos diferenciadores destas etnias que influenciaram na construção das religiões afro-brasileiras, primeiro por não ser este o objetivo central desta pesquisa, voltado para o estudo da intolerância religiosa, e também porque hoje, com a prevalência dos cultos de origem sudanesa e com o sincretismo religioso, tal diferenciação perde parte da sua importância. Como destaca Ramos (1940, p. 
alerta imediatamente que devemos atribuir à escravidão o não haver um nome genérico, africano, para designar todos os cultos. (CARNEIRO, 1959, p. 7-8).

[...] a presença de cultos de origem africana em todas essas áreas, na forma em que os encontramos, acompanha as linhas de dispersão (tráfico interno) de escravos até a abolição, embora os movimentos posteriores, e especialmente os atuais, da população brasileira já estejam, paulatinamente, ampliando, complicando e transformando este esquema.

Bastide (1971, p. 53) diz que do início da colonização até o fim do tráfico negreiro cerca de 3,5 milhões de negros foram arrancados do seu continente e foram trazidos como escravos para o Brasil. Este número sobre para 5 milhões nos estudos de Conrad (1985) e, considerando como um todo o continente africano, teriam sido traficados conforme Cashmore (2000, p. 189) entre 12 e 15 milhões de africanos. Assim, milhões de pessoas vindas de diferentes regiões da África, com características sociais, culturais e religiosas distintas, foram espalhadas no que se chamou diáspora africana ${ }^{14}$.

Santos (1986, p. 31), relata que os africanos de origem banta, do Congo e de Angola, foram trazidos para o Brasil durante o período da conquista e do desbravamento da colônia e espalhados em pequenos grupos por imensos territórios no Rio de Janeiro, São Paulo e Minas Gerais, numa época de comunicações difíceis e com centros urbanos em fase inicial de crescimento. Já os nagôs, para a autora, foram trazidos durante o último período da escravidão e concentrados em zonas urbanas em pleno apogeu nos Estados do Norte e do Nordeste, na Bahia e em Pernambuco, principalmente nas suas capitais, Salvador e Recife ${ }^{15}$.

135 e 137), "Sobrevivências dos cultos de procedência banto existem, como vimos, mas de difícil identificação, tão amalgamados se acham com elementos do fetichismo gêge-nagô, do espiritismo, do catolicismo. Com efeito, a religião dos negros e mestiços brasileiros é a resultante, como temos afirmado repetidas vezes, de um vasto sincretismo. [...] a mítica ioruba absorveu, no Brasil, todas as outras espécies religiosas."

14 Caputo (2012, p. 40) diz que a diáspora africana identifica o processo de dispersão dos negros que foram sequestrados de suas terras, levando consigo suas tradições, mantendo -as e recriando-as no mundo, inclusive no Brasil.

15 Para a maioria dos pesquisadores esta dispersão espaço-temporal diferenciada das principais etnias africanas vindas para o Brasil e o intenso comércio entre a Bahia e a costa africana, permitiram que os nagôs e suas tradições culturais e religiosas influenciassem de forma predominante a formação das religiões afro-brasileiras. Por terem chegado ao Brasil já no final do período escravocrata, eles conseguiram se manter em maior número que os seus antecessores, praticamente dizimados pela crueldade do período, e além disso, os nagôs estavam concentrados nos centros urbanos e isto fez profunda diferença no seu processo de construção de relações entre si e com a sociedade da época, fato que contribuiu decisivamente para a sobreposição da sua tradição sobre as demais e para a colocação da 
Alertando-nos para o erro existente na tentativa de universalização ou redução das designações dos cultos afro-brasileiros, Carneiro (1959) passa a comentar sobre a suposta origem de cada um deles localizando-os nos diversos Estados e Regiões do país.

O nome candomblé, segundo Carneiro $(1959$, p. 7$)$ surge a partir de uma das danças outrora correntes entre os escravos, nas fazendas de café: o candome ${ }^{16}$.

Parece que candome era o nome dado aos atabaques, pois os negros deportados do Brasil para Buenos Aires, como nos informa Bernardo Kordon, assim chamavam "al tamboril africano" e às danças executadas para regalo do tirano Rosas. $\mathrm{O} e$ (aberto) do final da palavra, que parece angolense, talvez seja o $e$ (fechado) que co-mumente se acrescenta às sílabas finais da frase nas línguas sudanesas,"modificado pela prosódia baiana, que o prefere (sapé, Tietê, roleta). Como decifrar, porém, o enigma que constitui a inclusão do / ou do $r$, para formar os grupos consonantais $b l$ ou $b r$, que as línguas sudanesas e bantos desconhecem? Podemos conjeturar, com segurança, que candomblé tenha sido imposto, de fora, ainda que não possamos imaginar como, aos cultos da Bahia. (CARNEIRO, 1959, p. 7-8) ${ }^{17}$.

Mello e Souza (2007) refere-se aos candomblés como "conjunto importante de práticas e crenças mágico-religiosas de matrizes africanas que germinou no Brasil [...] sendo do século XIX as primeiras referências a eles." (p. 115). Segundo a autora, apesar de pertencer à língua banto, no Brasil se refere a cultos religiosos de origem ioruba e daomeana ${ }^{18}$ onde as principais entidades sobrenaturais são os orixás, quando a influência ioruba é maior, e voduns, quando a influência daomeana se destaca. Os candomblés do século XIX são os calunduns do século XVIII, que descreveremos adiante, os seus sacerdotes ficaram conhecidos como pais e mães-de-santo, onde o termo santo, de nítida influência católica, refere-se à entidade incorporada

sua religião, o candomblé, como a mais legítima e pura representação da África no Brasil.

16 Para Caputo (2012, p. 41) o candomblé é uma tradição vivenciada sobretudo no culto aos ancestrais e aos Orixás. Ele é chamado em Pernambuco, de Xangô e de Candomblé, na Bahia. Para autora a expressão candomblé acabou aglutinando várias expressões religiosas de diferentes grupos africanos, talvez esta seja a maior manifestação da importância dos nagôs no nosso país. A prática dessa religião acontece em espaços chamados Ilé (casa, em yorubá, língua dos nagôs), roça, Egbé (comunidade, sociedade) ou terreiro (talvez seja a forma mais corrente utilizada para identificar os templos de matriz africana no Brasil).

17 Para Berkenbrock (1998), candomblé vem de candom, uma espécie de tambor. Para o autor a terminação -blé não é conhecida nas línguas sudanesas e seria provavelmente uma corruptela da língua no Brasil.

$18 \mathrm{Na}$ Bahia, os iorubas também ficaram conhecidos como nagôs, e os daomeanos, como jêjês. 
durante a possessão.

Sobre a macumba Carneiro $(1959$, p. 7$)$ relata que antes de dançar, os jongueiros ${ }^{19}$ executam movimentos especiais pedindo a bênção dos cumbas velhos, palavra que significa jongueiro experimentado.

[...] de acordo com esta explicação de um preto centenário: "Cumba é jongueiro rúim, que tem parte com o demônio, que faz feitiçaria, que faz macumba, reunião de cumbas." Como o vocábulo é sem dúvida angolense, a sua sílaba inicial talvez corresponda à partícula $b a$ que, nas línguas do grupo banto, se antepõe aos substantivos para a formação do plural, com provável assimilação do adjetivo feminino má. Nem todos os crentes se satisfazem com esta designação tradicional - e os cultos mais modernos, tocados de espiritismo, já se intitulam de Umbanda, em contraste com Quimbanda, ou seja, macumba. Esta seria a magia negra, a Umbanda, a magia branca. (CARNEIRO, 1959, p. 8).

Berkenbrock (1998) diz que macumba designa a religião afro-brasileira surgida principalmente no Rio de Janeiro e advinda da tradição religiosa banta (congo e angola), mas, ressalta que na atualidade muitas vezes o termo é utilizado de forma generalizada para designar as práticas ou cerimônias e ainda de forma pejorativa para designar os cultos de origem africana. No mesmo sentido Maggie (2001) diz que macumba poderá ter três designações: a) instrumento musical, tambor ou atabaque; b) designação da religião de possessão em termos amplos; e c) definição do próprio trabalho feito.

Sobre a umbanda, Prandi (2003) diz que se formou no século XX, no Sudeste, e que representa uma síntese do antigo candomblé da Bahia, transplantado para o Rio de Janeiro na passagem do século XIXI para o XX, com o espiritismo kardecista, chegado da França no final do século XIX. Para o autor ainda hoje é comum os umbandistas se chamarem de espíritas ou católicos, seja por engano ou até mesmo para fugir de repressões e discriminações. Vejamos, por exemplo, que um dos casos que analisamos nesta pesquisa ocorreu num terreiro de candomblé denominado Centro Espírita Umbandista São Bartolomeu e registrado na Federação de Umbandistas. Refletiremos sobre estas estratégias de fuga da opressão dos setores repressores do Estado mais adiante e de forma mais detida. Em outras épocas os católicos e os agentes de segurança pública designavam a umbanda de "baixo espiritismo", para

19 Além das formas afro-brasileiras mais conhecidas, há um grupo de religiões de caráter muito regional que parecem mais associadas a religiões indígenas, das quais herdaram o uso ritual do tabaco e a forma cabocla das entidades, mas que se constituíram sobretudo com base em estruturas e componentes rituais africanos, com traços católicos e espíritas,como é o caso da jurema, catimbó, pajelança, cura, babaçuê. (PRANDI, 1991; FERRETTI, 1994). 
diferenciá-la do espiritismo kardecista ${ }^{20}$.

Estas são para Carneiro $(1959$, p. 8) designações correntes na Bahia e proximidades ou em Regiões onde o candomblé baiano exerceu maior influência, pois, já na Amazônia e no Rio Grande do Sul os cultos são chamados batuque $e^{21}$ ou pará (batucajé na Bahia). Segundo o autor supõe-se que batuque não advém do verbo bater, mas de uma dança de roda angolana que é considerada uma das origens do nosso samba.

Por extensão, como sabemos, batuque se aplica a toda e qualquer função à base de atabaques. Exclusivamente de referência ao culto, há na Bahia a forma batucajé. De qualquer modo, trata-se de palavra profana. Herskovits e, posteriormente, Roger Bastide registraram pará no Rio Grande do Sul, esclarecendo que os cultos de Porto Alegre são chamados pará pelos crentes e batuque por estranhos. A palavra pará parece tupi, e não africana, - a menos que se verifique a hipótese, pouco provável, de ser uma deturpação de Bará, nome por que é conhecido entre os negros gaúchos o mensageiro Exu. (CARNEIRO, 1959, p. 8).

Ainda na Região amazônica Carneiro (1959, p. 8) refere-se ao babaçuê $\hat{e}^{22} \mathrm{e}$

20 A umbanda tem sido compreendida como uma religião brasileira de caráter sincrético e socialmente dialético, de culto aos ancestrais africanos, pretos-velhos, ancestrais africanos diretos, e aos caboclos, os ancestrais da terra Brasil, representantes de grupos que sofreram ou sofrem exclusão social. "A umbanda conservou do candomblé o sincretismo católico: mais que isto, assimilou preces, devoções e valores católicos que não fazem parte do universo do candomblé. Na sua constituição interna, a umbanda é muito mais sincrética que o candomblé." (PRANDI, 2003, p. 2).

21 O termo batuque, juntamente com samba, segundo estudos de Amaral (2007, p. 237241) marcaram presença tanto na correspondência policial quanto na documentação judicial. Para a autora é possível que em muitos casos os sambas e batuques referidos pelas autoridades nos seus relatórios fossem na verdade cerimônias religiosas, e não espaços de mero divertimento profano de escravos e negros libertos.

22 Culto afro-brasileiro jeje-nagô que teve influências da pajelança amazônica, do candomblé de caboclo, do catimbó e da umbanda. 
ao tambor ${ }^{23}$, do Maranhão, e ao xangô ${ }^{24}$ de Pernambuco e Alagoas, designação utilizada em boa parte do Nordeste, incluindo o Estado de Sergipe, onde focalizamos a nossa pesquisa. Por aqui também o termo calundu $u^{25}$ é referido pela literatura (AMARAL, 2007, p. 237). Calundu, segundo Marina de Mello e Souza (2007, p. 113), como eram chamados os cultos afro-brasileiros no século XVIII principalmente, é uma palavra originária do termo banto quilundo ${ }^{26}$, e é similar a um culto centro-africano conhecido como xinguila ${ }^{27}$.

Outra prática comum entre os africanos no Brasil eram as bolsas de man$\operatorname{dinga}^{28}$, relatada por Souza $(2007$, p. 114) como um hábito que se espalhou a partir

23 O Tambor de Mina surgiu na capital do Maranhão, se expandiu pelo Pará, Amazonas, outros Estados do Norte e para as capitais que receberam grande número de migrantes do Norte, como Rio de Janeiro e São Paulo. Embora hegemônico no Maranhão, o Tambor de Mina - Jeje, Nagô, Cambinda, foi sincretizado no passado com manifestação religiosa de origem indígena denominada Cura/Pajelança e com uma tradição religiosa afro-brasileira, surgida em Codó (MA), denominada Mata ou Terecô. A partir dos anos sessenta a Mina e a Mata passaram a ser influenciadas pela Umbanda, tanto na capital como no interior do Estado. Hoje, embora as casas de Mina mais antigas não tenham se filiado a Federações de Umbanda, muitos terreiros de Mina e de Mata adotaram a Umbanda e, apesar de continuem realizando rituais de Mina, Mata e Cura(3), se apresentam como de Umbanda e participam de atividades promovidas pela Federação como: a Festa de lemanjá, no ano novo, e a Procissão dos Orixás, no aniversário da fundação de São Luís. O Candomblé só penetrou de forma mais visível no Maranhão depois dos anos setenta, especialmente na Casa Fanti-Ashanti, sobre a qual trato especificamente em Desceu na Guma (1993) e em Tambor de Mina, Cura e Baião na Casa Fanti-Ashanti (1991). (FERRETI, 1996, p. 3)

24 Os cultos do Nordeste fizeram de Xangô, famoso rei de Oyó que se transformou em divindade, um substantivo comum, corrente em Pernambuco, Alagoas e outros Estados. (CARNEIRO, 1959, p. 8).

25 O termo calundu foi amplamente utilizado no século XVIII para denominar as práticas religiosas de origem africana. Já o termo candomblé tornou-se popular no século XIX, substituindo o termo calundu. A esse respeito, ver Nicolau Parés, A formação do candomblé, 2006, p.109-115 e Renato da Silveira, O candomblé da Barroquinha, 2006, cap. 3. O termo xangô, como sinônimo de terreiro, era utilizado em Alagoas e Pernambuco, como referimos anteriormente.

26 "[...] os imbangalas procuravam esses feiticeiros porque acreditavam que eles sabiam tudo o que se passava na outra vida. Eles eram tratados como se fossem semideuses e respondiam às perguntas que eram feitas não a ele, mas ao espírito consultado." (SOUZA, 2007, p. 113 e 114).

27 “[...] um nome genérico para qualquer espírito que possuísse uma pessoa, geralmente como punição pela falta de respeito ou veneração de um espírito ancestral, que acabava por debilitar e até mesmo matar aquele que fosse possuído." (SOUZA, 2007, p. 113).

28 "[...] pequenos sacos de pano ou de couro usados junto ao corpo, pendurados no pescoço, na cintura, dentro dos quais estava costurada uma variedade de ingredientes. Eles poderiam ser de origem animal, vegetal e mineral, mas o mais importante deles eram os 
da região habitada pelos mandes, ou mandingas, antigos súditos do reino do Mali na região da Alta Guiné, onde o islamismo se misturou às religiões tradicionais e que usadas na África, Portugal e no Brasil recebeu a atribuição de ter os mesmos poderes que um talismã ou amuleto tinha nas diversas culturas da época e chegou a ser considera a prática mágico-religiosa mais mestiça do Brasil colonial, agregando elementos cristãos, islâmicos, ameríndios e africanos tradicionais.

\subsection{RELIGIÕES AFRO-BRASILEIRAS: ELEMENTOS CARACTERIZADORES}

Este panorama nos serve para esclarecer a diversidade de religiões de origem ou presenças africanas ${ }^{29}$ existente no Brasil e do quanto que elas são parte da "[...] assimilação desses cultos pela sociedade brasileira, o que os torna [...] nacionais, de existência somente possível no Brasil, e não mais africanos". (CARNEIRO, 1959, p. 8).

Prandi (1995, p. 115) defende que a presença do negro na formação social do Brasil foi decisiva para dotar a cultura brasileira de um patrimônio mágico-religioso, desdobrado em inúmeras instituições e dimensões materiais e simbólicas, sagradas e profanas, de enorme importância para a identidade do país e de sua civilização. No que diz respeito à religião especificamente, como vimos anteriormente, os cultos trazidos pelos africanos deram origem a uma variedade de manifestações que aqui encontraram conformação específica, através de uma multiplicidade sincrética resultante do contato das religiões dos negros com o catolicismo do branco, mediado ou propiciado pelas relações sociais assimétricas existentes entre eles, também com as religiões indígenas e bem mais tarde, mas não menos significativamente, com o espiritismo kardecista.

Mas, as religiões de origem africana, apesar de toda a sua diversidade, possuem quatro características que lhes são comuns - uma delas principal, as outras dela decorrentes, mas todas importantes para identificá-las como de origem africana (CARNEIRO, 1959, p. 10-13):

1) A possessão pela divindade;

2) O caráter pessoal da divindade;

3) A consulta ao oráculo; e

4) A homenagem obrigatória ao mensageiro celeste que transmite às divindades os desejos dos humanos.

papéis dobrados nos quais estavam escritas orações católicas ou muçulmanas." (SOUZA, 2007, p. 114).

29 Alguns autores, como Martha Sales e Brice Sogbossi, rejeitam o termo matriz africana para denominar as religiões que não sejam o candomblé. Segundo estes estudos, apenas o candomblé é uma verdadeira religião de matriz africana, possuindo as demais apenas a "presença" de elementos advindos da África. (SALLES, SOGBOSI, 2008). 


\section{5)}

Tratando da primeira e mais importante característica dos cultos de origem africana existentes no Brasil, Carneiro (1959, p. 11), destaca que tais cultos são os únicos existentes no país onde "a divindade se apossa do crente, [...] servindo-se dele como instrumento para a sua comunicação com os mortais".

A possessão também se dá no espiritismo e na pajelança, mas em condições diferentes: no espiritismo são os mortos, e não as divindades, que se incorporam nos crentes; na pajelança, embora sejam as divindades dos rios e das florestas que se apresentam, somente o pajé, e não os crentes em geral, é possuído por elas. Assim, não é o fenômeno da possessão, por si mesmo, que caracteriza os cultos de origem africana, mas a circunstância de ser a divindade o agente da possessão.

Esta especificidade talvez se constitua num dos principais elementos responsáveis pelas manifestações discriminatórias contra as religiões afro-brasileiras ou a origem da desconsideração da sua classificação enquanto religião. O medo e o espanto diante da cerimônia de incorporação são relatos comuns daqueles que se manifestam sobre os cultos de origem africana.

Em uma das obras mais importantes sobre o tema religiões de origem africana no Brasil, Ramos (1951), em "O negro brasileiro - Etnologia religiosa" nos apresenta a sua descrição sobre o fenômeno da possessão:

Nas danças ao santo, chega um momento em que o orixá "penetra" na cabeça da filha de santo. É o fenômeno do estado de santo, verdadeira possessão a cujo estudo reservaremos um capítulo especial. A filha de santo fica animada de movimentos contorsivos que se agravam progressivamente até cair extenuada. Retiram-na então para a sua camarinha e lá a mãe de santo a veste com as insígnias do santo a que pertence. Findo isto, volta à sala do terreiro, agora reverenciada por todos os presentes que se curvam à passagem e recomeça as danças e os cânticos. (RAMOS, 1951, p. 73-74)

Com relação à segunda característica, o caráter pessoal da divindade, esclarece Carneiro (1959, p. 11), que aquela possessão da divindade se exerce não sobre todos os crentes indistintamente, mas apenas sobre alguns eleitos, especialmente do sexo feminino.

Acredita-se, em todo o Brasil, que cada pessoa tem, velando por si, uma divindade protetora. $\mathrm{O}$ privilégio de servir de instrumento (cavalo) à divindade está reservado a alguns, que precisam iniciar-se (assentar o santo) para recebê-la. Os demais devem submeter-se, entretanto, a determi- 
nadas cerimônias para poder servi-la de outra forma. A iniciação prepara o crente como devoto e como altar para a divindade protetora, que tem caráter pessoal - isto é, embora seja Ôgún ou Ômòlu, é o Ôgún ou o Ômòlu particular do crente, e, em alguns lugares, tem mesmo um nome próprio, por ela mesma declarado ao final do processo de iniciação. Daí dizer-se "o Ôgún de Maria", "o Xangô de Josefa" ou "a Yansã de Rosa", necessariamente distintos do Ôgún, do Xangô ou da Yansã de outras pessoas. Deste modo, cada cavalo está preparado para receber apenas a sua divindade protetora, e nenhuma outra, de acordo com o modelo nagô, ou as suas divindades protetoras, em certos cultos. (CARNEIRO, 1959, p. 11).

Deste modo, o escolhido é detentor do "[...] privilégio de servir como instrumento (cavalo), à divindade." (CARNEIRO, 1959, p. 11), devendo para isto assumir uma série de compromissos e obrigações perante a sua comunidade ${ }^{30}$.

As últimas características - o Ifá, oráculo, chamado de "jogo de búzios ${ }^{31}$ ", e Exu, o mensageiro celeste - representam os seres intermediários entre as divindades e os homens e ajudam a caracterizar os cultos de origem africana. O Ifá traz aos homens a palavra das divindades e situa-se em posição superior a Exu, que transmite às divindades os desejos dos homens. (CARNEIRO, 1959, p. 12). Assim, percebemos como que estas características comuns a todos os cultos de origem africana - a possessão pela divindade, o caráter pessoal desta, a consulta ao adivinho e o "despacho" para Exu - demonstram que esses cultos constituem realmente uma unidade, que assume formas diversas em cada lugar.

\subsection{O ESPAÇO-TEMPO NACIONAL E AS RELIGIÕES DE ORIGEM AFRICA- NA}

Para Prandi (1995, p. 117) podemos identificar duas matrizes africanas básicas que jogaram papel decisivo na formação das religiões negras no Brasil: sudaneses e bantos. Ambas as tradições, cada uma contemplando uma multiplicidade de variantes, têm em comum princípios fundantes bem definidos: o politeísmo e a concepção de que os deuses são privativos de indivíduos e grupos, os deuses como mediação das forças da natureza, o contato com a divindade através do transe, a decifração do destino pelo oráculo, o culto à ancestralidade e o favorecimento dos

30 Os eleitos precisam passar por um processo de iniciação (assentar o santo) para que a divindade possa exercer a possessão no crente. "A iniciação prepara o crente como devoto e como altar para a divindade protetora." (CARNEIRO, 1959, p. 11). Sobre o processo de iniciação Ramos (1940, p. 65-68).

31 "Certamente por não terem vindo para o Brasil elementos da sua ordem sacerdotal, o oráculo Ifá, generalizado entre as tribos do litoral do Golfo da Guiné, aqui chegou na 'mais modesta' das suas formas: a interpretação de oito ou dezesseis búzios, dispostos em rosário ou soltos, atirados pelo adivinho." (CARNEIRO, 1959, p. 12). 
deuses pelo sacrifício ritual.

Carneiro (1959, p. 13-18) tomando por base determinados aspectos peculiares e utilizando o artifício de dividir o país naquelas áreas em que os cultos se registram, elabora uma classificação das religiões de origem africana no Brasil (Fig. $1)$.

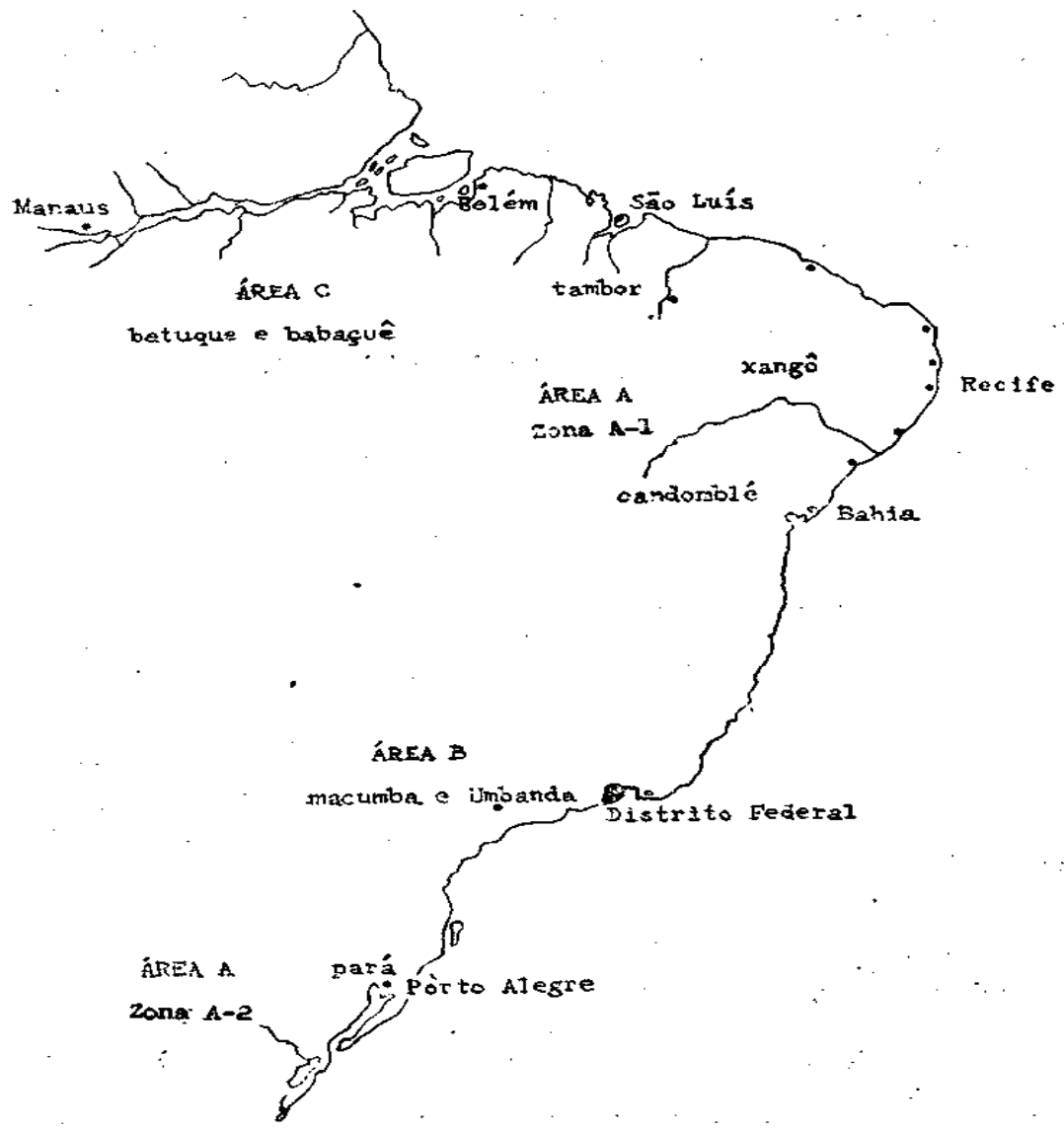

Fig. 1 - Cultos afro-brasileiros segundo a área. (CARNEIRO, 1959, p. 14).

Para o autor, na faixa litorânea compreendida entre a Bahia e o Maranhão (Zona A-1) e no Rio Grande do Sul (Zona A-2) constituiriam a primeira dessas áreas (Área A), a mais importante. Subdividindo a Zona A-1, o autor constrói três subáreas: 1) a do candomblé (Leste Septentrional); 2) a do xangô (Nordeste Oriental) e 3) a do tambor (Nordeste Ocidental). Os batuques ou parás do Rio Grande do Sul são representativos da Zona A-2, que completa a Área A, como uma reprodução, adaptada às condições gaúchas, do candomblé da Bahia. Na Área A estão os cultos 
em que a teogonia e a liturgia são realmente ligados à tradição africana, quase sem diferenças apreciáveis em confronto com as religiões de que descendem. (CARNEIRO, 1959, p. 15).

Para Carneiro (1959, p. 15) uma segunda área (Área B) seria a região compreendida pelo Distrito Federal, Estado do Rio, São Paulo e, possivelmente, Minas Gerais: a área da macumba. Conforme o autor, nesta Área os cultos apresentavamse muito densos na região metropolitana do Distrito Federal, que inclui todos os municípios fluminenses, capixabas, mineiros e paulistas que dela dependem, e se tornavam mais raros à medida que se aproximam de São Paulo e de Belo Horizonte.

Tendo chegado ao Rio de Janeiro, centro da área, mais ou menos por ocasião da sua elevação a capital do país. O modelo experimentou um passageiro esplendor, que, como parecem demonstrá-lo as reportagens de João do Rio, se apagou totalmente em começos deste século. Debilitara-se com as concessões feitas às tradições culturais de Angola, de onde procedia a maior parte dos negros da região, - a aceitação das suas danças semi-religiosas, o jongo e o Caxambu, e do seu culto dos mortos, este último uma ponte para a aceitação posterior do espiritismo kardecista; com a adesão de brasileiros de todos os quadrantes da Federação e de todas as camadas sociais; com o beneplácito dado a concepções e práticas do espiritismo e do ocultismo e com a complacência demonstrada em relação a novas divindades, caboclas e negras. Embora alguns cultos da Bahia se tenham transferido para o Rio de Janeiro, reforçando o contingente original, em nenhuma outra área os cultos de origem africana se apresentam em tão adiantado estágio de nacionalização. (CARNEIRO, 1959, p. 15).

Na Área B o autor distingue dois tipos de cultos: 1) a macumba propriamente dita, com a possessão pela divindade induzida pelos atabaques, e 2) a Umban$d a$, penetrada de espiritismo. A distinção entre ambos os tipos segue, aparentemente, a linha de classe - a macumba satisfaz as necessidades religiosas dos pobres, a Um$b a n d a$, as dos ricos. Para o autor, na Área B estão os cultos que mais se distanciaram das tradições africanas e abriram espaço para influências vindas de outras religiões e nações, de modo que nesta Área é onde "[...] os cultos de origem africana se apresentam em tão adiantado estágio de nacionalização." (CARNEIRO, 1959, p. 15).

Uma terceira e última área (Área C) seria a Amazônia, especialmente as cidades de Belém e Manaus, onde se produziu um fenômeno semelhante ao indicado no centro-sul, ou seja, os cultos de origem africana, tendo encontrado uma forte tradição local, neste caso a da pajelança, teve de adaptar o seu modelo de culto às condições do ambiente, originando dois tipos de culto nesta Área: o batuque e o babaçuê, que correspondem às variedades transmitidas à Amazônia, respectivamente, por elementos egressos da Casa de Nagô e da Casa das Minas de São Luis. (CAR- 
NEIRO, 1959, p. 16).

Os cultos da área A resultaram do contato simples e direto entre as concepções religiosas jêje-nagôs, quando estas sobrepujaram as das outras tribos, e o catolicismo popular. Os cultos das áreas B e C exigem uma explicação menos singela, por se terem originado de um segundo contato do modêlo de culto vigente na área $\mathrm{A}$, ora com formas semi-religiosas angolenses (área B), ora com a pajelança amazônica, resultado, por sua vez, de contato anterior entre práticas mágicas dos nativos e o catolicismo popular (área C). (CARNEIRO, 1959, p. 16)

É como destaca Ramos (1951), com as devidas ressalvas à sua ideia de existência de cultos civilizados e de cultos fetichistas, onde este está em nível inferior àquele:

[...] as religiões e cultos do negro e do mestiço brasileiros contemporâneos, embora se lhes reconheça a origem africana, são a resultante de uma mescla curiosa, onde várias formas míticas entraram em contato, umas se fundindo a outras, as mais adiantadas absorvendo as mais atrasadas, originando uma verdadeira simbiose ou sincretismo religioso. (RAMOS, 1951, p. 137).

Este fenômeno é descrito por Ramos (1940) como um problema, pois tem gerado a propagação dos cultos de origem africana pelo país: "No Brasil, a obra do sincretismo continuou e hoje já é difícil reconhecer os elementos puros de origem. Os candomblés, macumbas e catimbós com esse sincretismo pululam em vários pontos do Brasil." (RAMOS, 1951, p. 138).

Mello e Souza (2007) reflete que realmente no século XIX as ruas das principais cidades brasileiras estavam sempre cheias de escravos ${ }^{32} \mathrm{e}$ isto proporcionou que aspectos da cultura africana de misturassem e convivessem com a cultura portuguesa, e, além disso, que nesses intercâmbios entre negros africanos e brancos portugueses fosse acrescentado ainda um "tempero ameríndio" (p. 110). Assim, não só os escravos e negros livres sofriam influências dos seus colonizadores, mas, estes também de relacionavam com as práticas daqueles e muitas vezes recorriam aos saberes destes grupos africanos para, por exemplo, cuidar dos males que os afligiam.

32 Era comum neste período, explica Souza (2007, p. 110) que os escravos nas ruas das grandes cidades realizassem atividades como a venda de legumes e animais, alimentos prontos em tabuleiros, transportassem água, sacos de mantimentos, fardos de tecidos que chegavam nos navios, cadeirinhas das senhoras da sociedade. Assim eles causavam aos estrangeiros que aqui desembarcavam o espanto de encontra um pedaço da África na Améri$\mathrm{ca}$, dada a quantidade e variedade de africanos que se podia ver em todo lugar. 
Para a autora, era exatamente sobre este campo, o das práticas mágico-religiosas, que a classe senhorial detinha mais conhecimento em relação à vida das comunidades negras vindas da África.

Sobre o sincretismo religioso ${ }^{33}$, Prandi (1995, p. 118), diz que candomblé e catolicismo sempre estiveram juntos, como se este fosse a face branca daquele, sem antagonismos ou contradições. Para o autor apesar da intransigência e perseguição, quase sempre violenta, do branco aos candomblés, "o negro pode por muito tempo ter seus próprios deuses, sendo assim africano, e ser católico, sendo assim brasileiro", e isso propiciou que a maior parte dos descendentes dos antigos escravos deixasse os velhos deuses africanos para trás, aderindo à sociedade do branco, munida unicamente da religião do branco.

Esse quadro se agrava com o surgimento das grandes cidades do Sudeste, de um grande contingente de proletariado pobre, do trabalhador negro livre ${ }^{34}$ e de uma nova religião: a umbanda ${ }^{35}$. Assim, o surgimento desta sociedade de classes diluiu o sentido da identidade racial do negro com os cultos de origem africana e, construída a nova identidade do negro como pobre, estes são reconhecidos como majoritariamente católicos, e aqueles que desacreditam da religião católica, buscam outras alternativas, especialmente as religiões pentecostais, abertas a negros e brancos, desde que pobres. (PRANDI, 1995, p. 118-119).

Esse processo, que transformava o negro em pobre, juntou o pobre negro com o pobre branco numa mesma categoria. No espaço sem identidade da grande cidade que então apenas se desenhava, aglomerava-se uma população cujas referências originais tinham sido estilhaçadas pelas mudanças em curso, fossem eles negros ou brancos, ou fossem ainda "misturados", como os têm sonhado as ideologias brasileiras dos morenismos e do branqueamento da raça. (PRANDI, 1995, p. 119).

33 Para Prandi (1995, p. 118), "o sincretismo é um simples, porém, eficaz sistema de equivalências e justaposições entre as religiões negras e o catolicismo ibérico de preferências devocionais a uma infinidade de santos quase heveméricos na concepção popular".

34 "O negro empregado, em geral, nas ocupações mais ligadas aos setores de serviço pessoal ou às atividades manuais não qualificadas, frequentemente em posição formalmente marginal nos bolsões informais associados ao mercado de força de trabalho." (PRANDI, 1995, p. 118).

35 Nesta inflexão estrutural da sociedade brasileira, a umbanda surgiu como uma redefinição de origens, símbolos e desideratos. Suas fontes estão na confluência dos candomblés de caboclo e de angola, via pela qual herdou os orixás como cabeças de falanges de espíritos desencarnados de velhos índios e antigos escravos, com o kardecismo, com o qual aprendeu não só a lidar com a concepção do karma de herança hindu, mas também com uma concepção ética da expressão religiosa cristã e com a ideia de progresso (material, intelectual e espiritual) alcançável pela experiência religiosa, porém racional. (PRANDI, 1995, p. 19). 


\section{CONCLUSÃO}

Apesar da desagregação da figura do negro das religiões de origem africana, como defendem alguns dos nossos referenciais, é preciso atentarmos para o fato de que quando identificamos os cultos de origem africana como espaços de preservação do patrimônio cultural negro, logo eles passam a ser encarados pelo outro como fonte do mal, expressão do indesejável, veículo da perdição, e como o preconceito corrente diz que tudo que é do negro não presta, especialmente a religião, a falsa religião, chamada por muitos de magia, macumba, feitiçaria, seita e magia negra, aí então sim a referência à origem negra é imediata. $\mathrm{E}$ daí advêm os preconceitos e a resistência em reconhece-los como religião.

Por conta disto é que acreditamos que os atos de intolerância contra as religiões de origem africana, inclusive os expressos através de decisões judiciais, advêm do racismo brasileiro e trazem consigo ranços ainda não digeridos do nosso processo de colonização e do longo período de escravização negra no Brasil. Mas não só. Cremos que os fundamentalismos e a intolerância, muito fortes no passado a partir da figura da Igreja Católica e do aparato de repressão do Estado, e hoje, no presente, cada vez mais perceptíveis na sociedade brasileira nos atos e falas das novas igrejas evangélicas e dos seus adeptos e na prestação de serviços públicos, como o acesso à justiça, escondem um desejo de superioridade cultural e política, que, de alguma forma, passa pela ignorância a respeito do outro e pela perpetuação de teorias excludentes incompatíveis com o atual desenvolvimento de um estado democrático de direito e constitucionalmente laico. Contra a ignorância e pela construção de um novo paradigma sobre a amplitude da liberdade religiosa é que trabalhamos nesse artigo, a partir da apresentação de uma série de elementos conceituais e históricos capazes de munir o leitor, que pode ser inclusive um julgador, de informações importantes para a construção de sua opinião, do seu convencimento e de uma sociedade melhor.

\section{REFERÊNCIAS}

ALBUQUERQUE, Wlamyra R. de e FRAGA FILHO, Walter. Uma história do negro no Brasil. Salvador: Centro de Estudos Afro-Orientais; Brasília: Fundação Cultural Palmares, 2006. 320p.

AMARAL, Sharyse Piroupo do. Escravidão, Liberdade e Resistência em Sergipe: Cotinguiba, 1860-1888. Tese de doutorado. Universidade Federal da Bahia, Faculdade de Filosofia e Ciências Humanas, 2007.

BASTIDE, Roger. As religiões africana no Brasil. São Paulo. Pioneira/USP, 1985. . O candomblé da Bahia: rito nagô. São Paulo, Nacional, 2001.

BERKENBROCK, Volney J. A experiência dos orixás - um estudo sobre a expe- 
riência religiosa no candomblé. Rio de Janeiro: Vozes, 1998.

CAPUTO, Stela Guedes. Educação nos terreiros e como a escola se relaciona com crianças de candomblé. Rio de Janeiro: Pallas, 2012.

CARNEIRO, Edison. Candomblés da Bahia. Rio de Janeiro, Ouro, 1959.

CASHMORE, Ellis. Dicionário de relações étnicas e raciais. São Paulo: Summus, 200.

CONRAD, Robert Edgar. Tumbeiros, o tráfico de escravos para o Brasil. São Paulo: Brasiliense, 1985.

DANTAS, Beatriz Góis. 1982. Vovô Nagô Papai Branco; usos e abusos da África no Brasil. Dissertação de mestrado. Unicamp, Campinas, mimeo.

FAUSTO, Boris. História do Brasil. São Paulo : Edusp, 1996.

FERRETTI, Mundicarmo (1994). Terra de caboclo. São Luís: Plano Editorial/SECMA.

FERRETTI, Sérgio Figueiredo. Religiões afro-brasileiras na perspectiva de Gramsci Jornada sobre Gramsci. UFMA, 18 - 22/10/1999.

FREYRE, Gilberto. Interpretação do Brasil. Aspectos da Formação Social Brasileira como Processo de Amalgamento de Raças e Culturas. Rio de Janeiro: José Olympio, 1947.

MAGGIE, Yvonne. Guerra de Orixá: um estudo de ritual e conflito. Rio de Janeiro, Zahar, 2001.

MEDEIROS, Carlos Alberto. Na lei e na raça. Rio de Janeiro: DP\&A Editora, 2004.

PRANDI, Reginaldo. O Brasil com axé: candomblé e umbanda no mercado religioso. Estud. av. [online]. 2004, vol.18, n.52, pp. 223-238. ISSN 0103-4014.

. De africano a brasileiro: etnia, identidade, religião. Revista USP, São Paulo, n.46, p. 52-65, junho/agosto 2000.

. "As religiões negras do Brasil: para uma sociologia dos cultos

afro-brasileiros.” Revista USP 28 (dez.-fev.), 1996. P. 64-83.

. Raça e religião. Novos estudos CEBRAP. n. 42. 1995, p. 113-129.

RAMOS, Artur. O negro brasileiro, etnografia religiosa. São Paulo. Nacional, 1951.

RODRIGUES, Nina. Os africanos no Brasil. São Paulo, Nacional, 1932.

SANTOS, Boaventura de Sousa. Poderá o direito ser emancipatório?. Revista Críticas de Ciências Sociais, 65, Maio 2003: 3-76. 
SANTOS, Juana Albein dos. Os nagôs e a morte. Petrópolis: Vozes, 1999.

SILVA JR, Hédio. Notas sobre sistema jurídico e intolerância religiosa no Brasil. In: SILVA, Vagner Gonçalves da (org.) Intolerância Religiosa: impactos do neopentecostalismo no campo religioso afro-brasileiro. São Paulo: EDUSP, 2007.

SILVA, Vagner Gonçalves da (org.) Intolerância Religiosa: impactos do neopentecostalismo no campo religioso afro-brasileiro. São Paulo: EDUSP, 2007.

SOARES, Stênio. "Anos da Chibata": perseguição aos cultos afro-pessoenses e o surgimento das Federações. CAOS - Revista Eletrônica de Ciências Sociais. n. 14 Setembro de 2009, p. $134-155$.

SOGBOSSI, Hippolyte Brice. COSTA, Martha Sales. RELIGIÕES BRASILEIRAS DE PRESENÇA AFRICANA E POLÍTICAS PÚBLICAS NO BRASIL: ALGUMAS CONSIDERAÇÕES. Revista Debates do NER, Universidade Federal do Rio Grande do Sul, v.2, n. 13, Porto Alegre, 2008.

SOUZA, Marina de Mello e. África e Brasil africano. 2 ed. São Paulo: Ática, 2007. 